\title{
INFLUENCE OF VAPORIZATION AND IMPREGNATION OF SILVER NANOPARTICLES ON THE DRYING RATE OF Eucalyptus pellita F. MUELL.
}

\author{
José Henrique Camargo Pace1*, João Vicente de Figueiredo Latorraca², Alexandre Monteiro de Carvalho², \\ Glaycianne Christine Vieira dos Santos ${ }^{4}$, Sabrina Mayer de Almeida ${ }^{5}$, Fernando José Borges Gomes ${ }^{6}$ \\ ${ }^{1 *}$ Federal Rural University of Rio de Janeiro, Postgraduate Program in Environmental and Forest Sciences, Seropédica, state of Rio de \\ Janeiro, Brazil - josehcpace@gmail.com (*AUTHOR FOR CORRESPONDENCE) \\ ${ }^{2}$ Federal Rural University of Rio de Janeiro, Department of Forest Products, Seropédica, state of Rio de Janeiro, Brazil - \\ latorraca@hotmail.com \\ ${ }^{3}$ Federal Rural University of Rio de Janeiro, Department of Forest Products, Seropédica, state of Rio de Janeiro, Brazil - \\ amcarvalho.ufrrj@gmail.com \\ ${ }^{4}$ Federal Rural University of Rio de Janeiro, Postgraduate Program in Environmental and Forest Sciences, Seropédica, state of Rio de \\ Janeiro, Brazil - annechristine.santos@hotmail.com \\ ${ }^{5}$ Federal Rural University of Rio de Janeiro, Undergraduation in Forest Engineering, Seropédica, state of Rio de Janeiro, Brazil - \\ sabrinamayer.almeida@gmail.com \\ ${ }^{6}$ Federal Rural University of Rio de Janeiro, Department of Forest Products, Seropédica, state of Rio de Janeiro, Brazil - \\ fjbgomes@yahoo.com.br \\ Received for publication: 18/07/2018 - Accepted for publication: 11/10/2018
}

\begin{abstract}
Resumo
Influência da vaporização e de impregnação de nanopartículas de prata na taxa de secagem da madeira de Eucalyptus pellita F. Muell. O objetivo deste estudo foi avaliar o efeito da vaporização e da impregnação de nanopartículas de prata nas propriedades da madeira de Eucalyptus pellita. Para tanto, amostras de três regiões radiais da madeira, oriundas de três árvores, foram separadas em madeiras vaporizadas durante 12 e $24 \mathrm{~h}$ e madeiras imersas em solução de nanopartículas de prata com e sem aplicação prévia de vácuo $(750 \mathrm{mmHg})$. Análises anatômicas, físicas e químicas da madeira foram realizadas a fim de avaliar o efeito dos tratamentos. A taxa de secagem da madeira foi determinada em faixas de umidade antes e após o ponto de saturação das fibras (PSF). Em geral, os tratamentos não modificaram as características anatômicas, densidade e permeabilidade da madeira nas três regiões radiais; contudo, a vaporização por $24 \mathrm{~h}$ reduziu o teor de extrativos totais na madeira. Esses resultados contribuíram para que ganhos na taxa de secagem antes e após o ponto de saturação das fibras fossem obtidos. O efeito da impregnação de nanopartículas com vácuo e os dois períodos de vaporização resultaram nas maiores taxas de secagem, sendo que o tempo de $24 \mathrm{~h}$ de vaporização obteve as melhores médias entre todos os tratamentos. A vaporização por $24 \mathrm{~h}$ e a impregnação de nanoparticulas apresentaram efeitos positivos na taxa de secagem.

Palavras-chave: secagem da madeira, nanotecnologia, permeabilidade da madeira.
\end{abstract}

\begin{abstract}
The aim of this study was to evaluate the effect of vaporization and impregnation of silver nanoparticles on the Eucalyptus pellita wood properties. For that, samples of three radial regions of the wood from three trees were vaporized for 12 and 24 hours and later on, they were immersed in solution of silver nanoparticles with and without application of vacuum $(750 \mathrm{~mm} . \mathrm{Hg})$. Anatomical, physical and chemical analyzes of the wood were carried out in order to evaluate the effect of the treatments. The drying rate of the wood was determined in moisture bands before and after the fiber saturation point. Generally, the treatments did not modify the anatomical characteristics, permeability, and wood density in the three radial regions; however, the vaporization for $24 \mathrm{~h}$ reduced the total extractive content in the wood. These results contributed in obtaining gains in the drying rate before and after the fiber saturation point. The effect of impregnation of nanoparticles with vacuum preceded by two periods of vaporization resulted in higher drying rates and the time of $24 \mathrm{~h}$ stood out, resulting in the best averages among all treatments. The impregnation of nanoparticles had positive effects on the drying rate.

Keywords: wood drying, nanotechnology, wood permeability.
\end{abstract}

\section{INTRODUCTION}

During the drying process it is necessary to minimize the undesirable effects to the factors related to the wood, such as the thermal diffusivity, the related physical properties with the dimensional movement, the drying tensions, density and wood permeability (TARMIAN et al., 2012; LUIS et al., 2017).

FLORESTA, Curitiba, PR, v. 49, n. 3, p. 579 - 586, jul/set 2019.

Pace, J. H. C. et.al.

ISSN eletrônico 1982-4688

DOI: $10.5380 /$ rf.v49 i3.60588 
Drying rate is an important variable in wood behavior control during the drying process. In general, eucalyptus wood presents low permeability which is responsible for the significant humidity gradient and consequently tension formation that complicates its drying process (ELEOTÉRIO et al., 2014; REZENDE et al., 2015). According to Bal and Bektas (2012), vaporization is a treatment possibility that modifies wood hygroscopic properties. The application of elevated temperatures initially causes carbohydrates degradation, mainly hemicelluloses and amorphus regions of cellulose chains (LUÍS et al., 2017), and by extended periods and higher temperatures. It modifies completely the wood permeability due to the appearance of microcracks in cellular wall (CALONEGO et al., 2014).

Vapor treatment allows drying process optimization due to permeability increase, resulting from pits and vessels clearance (ALEXIOU et al., 1990). In such a way, the permeability is directly related to anatomical structures (BARAÚNA et al. , 2014), as well as with the balance of the water entrance and exit from the wood and the easiness of preservative fluid penetration (BREADS et al., 2013; GAO et al., 2015).

The wood impregnation with silver nanoparticles has revealed a worthwhile process, promoting alterations in wood characteristics internally and superficially, providing, in some cases, improvements in durability as well as physical and mechanical properties (DASHTI et al., 2012; TAGHIYARI et al., 2012; MONTAZER, ALIMOHAMMADI, 2012; TAGHIYARI et al., 2014; TAGHIYARI et al., 2015; GAO et al., 2015).

Regarding what was exposed, it was evaluated the hypothesis that vaporization and impregnation of wood with silver nanoparticles promote modifications in the drying process, influenced by the material chemistry and anatomy. Thus, the objective of this experiment was to evaluate the wood technological behavior of Eucalyptus pellita F. Muell. treated previously with vapor and impregnated with silver (Ag) nanoparticles.

\section{MATERIAL AND METHODS}

\section{Delineation, collection and preparation of the material}

For the acquisition of wood samples, three 22-year-old trees of Pellita Eucalyptus had been cutted, planted $3 \times 2 \mathrm{~m}$ of spacing in a population located in the campus of the Rural Federal University of Rio De Janeiro - UFRRJ in Seropédica, state of Rio de Janeiro, Brazil (Lat 22.7604 ${ }^{\circ}$, Lon $43.7078^{\circ}$ ). Samples of these trees were deposited in the xylotheque of the Forest Institute of the Rural Federal University of Rio de Janeiro, under the registration number: 7711, 7712 and 7713. After the cutting, the first log of each tree, with $4.5 \mathrm{~m}$ of length, was conducted to the primary cut with the assistance of vertical band saw in order to obtain planks with 3 inch radial thickness. After that, they were parted in pieces with the following dimentions: $33 \times 2.5 \times 5 \mathrm{~cm}$ (length $\mathrm{x}$ thickness $\mathrm{x}$ width), enclosing three radial positions from the pith towards the vascular cambium, denominated: Heartwood/Sapwood Transition Zone (HST), Intermediate Heartwood (ITH) and Internal Heartwood (INH)

The samples of each region were distributerd in three groups: 1) No treatment samples; 2) samples treated only with nanoparticles; and 3) samples treated only with vapor (Table 1), totalizing 5 treatments per radial position. Vaporizarion was applied in the wood pieces in two constant periods with $12 \mathrm{~h}$ and $24 \mathrm{~h}$ of duration.

Tabela 1. Delineamento experimental aplicado para as três regiões radias da madeira: Transição Cerne/Alburno (TCA), Cerne Intermediário (CIT) e Cerne Interno (CIN).

Table 1. Experimental design applied to the three radiated regions of the wood: Heartwood/Sapwood Transition (HST), Intermediate Heartwood (ITH) and Internal Heartwood (INH).

\begin{tabular}{lccrr}
\hline \multirow{2}{*}{ Radial position } & \multirow{2}{*}{ Vaporization (h) } & $\begin{array}{r}\text { Impregnation with Nano } \\
\text { Ag }\end{array}$ & Vacuum Application & Code \\
\hline External (HST) & $\mathrm{N}$ & $\mathrm{N}$ & - & Control \\
Intermediate (ITH) & $\mathrm{N}$ & $\mathrm{Y}$ & $\mathrm{Y}$ & Sample \\
Internal (INH) & $\mathrm{N}$ & $\mathrm{Y}$ & $\mathrm{N}$ & $\mathrm{WV}$ \\
& 12 & $\mathrm{~N}$ & - & $\mathrm{NV}$ \\
& 24 & $\mathrm{~N}$ & - & Vap12 \\
& & $\mathrm{N}$ & Vap24 \\
\hline
\end{tabular}

Nano Ag (silver nanoparticles); $\mathrm{N}=$ no; $\mathrm{Y}=$ yes; WV = nanoparticles impregnation with vacuum; $\mathrm{NV}=$ nanoparticles impregnation without vacuum; Vap12 = wood vaporization for $12 \mathrm{~h}$; Vap24 = wood vaporizarion for $24 \mathrm{~h}$.

\section{Vaporization and impregnation of nanopartículas}

Initially, the wood was vaporized using an horizontal autoclave with capacity of $0.18 \mathrm{~m}^{3}$ approximately, providing temperature and pressure control. The maximum temperature applicated was $98^{\circ} \mathrm{C} \pm 2$ and the relative humidity was $90 \% \pm 5$ proceeding from vapor generation through a boiler with the capacity of $12 \mathrm{Kg}$ vapor/hour. 
The sample impregnation with silver nanoparticles (NPs) was performed through simple immersion, using an acrylic chamber with $45 \times 40 \times 50 \mathrm{~cm}$ of dimention. The wood immersion in destilled water with silver NPs in suspension (22 ppm) occurred with and without initial vacuum application of $750 \mathrm{mmHg}$ for five minutes. This solution consisted by silver NPs with size between 5 and $20 \mathrm{~nm}$, which characterizes as colloid with exceptional stability and purity, i. e., without surfactants presence, avoiding precipitates formation. The wood remained submerged in the solution for $30 \mathrm{~min}$.

\section{Anatomical analyses}

For the anatomical analyses, a sample of $2 \mathrm{~cm}$ of thickness was removed from the extremity of each treatment parts. Later, this sample was cutted in $1 \mathrm{x} 1 \mathrm{~cm}$ blocks for observation in Scanning Electron Microscope (SEM), aiming at the verification of nanoparticles impregnation and vascular contents and the obtention of transversal histological cuts in slide microtome.

Semi-permanent blades were prepared to the measurement of the tangential diameter of the vessels through digital images captured by a monochromatic camera connected to the trilocular microscope. 1 The used procedures followed the International Association of Wood Anatomy Committee (IAWA) (1989) recomendations.

At first, the frequency of the vessels (tissue. $\mathrm{mm}^{-2}$ ) also followed the methodology proposed by IAWA (1989). For that, digitalized images from the transversal face of cilindrical samples were used, being prepared to the air permeability test.

\section{Chemical analyses}

For the determination of total extratives content, the procedures described by Abreu et al. (2006) were used, following an eluotropic sequence with the solvents: cyclohexane, acetate and methanol. Each extraction was performed during six hours. After each extraction the solution was placed in a rotary evaporator (Rotavapor) so it was possible, using vacuum and heat, to concentrate and weigh the extracted portion in each type of solvent. The contents of lignin (soluble and insoluble in acid), uronic acid, acetyl group and carbohydrates (xylan, mannan, galactan, arabinan and glucan) were determined according to the procedures proposed by Tappi T222 (2000), Scott (1995), Solar et al. (1987) and Wallis et al. (1996). Additionally, chemical analyses were performed in the vaporized and without treatment samples.

\section{Wood drying rate}

After vaporization and nanoparticle impregnation treatment, all samples went through a drying process in climatized room with temperature at $20^{\circ} \mathrm{C} \pm 2$ and relative humidity at $65 \% \pm 5$. During the drying process, at each 2 hours the mass and respective dimentions (width, thickness and length) of all samples were measured. This process was used in order to register water mass loss and it was 54 days long until the obtention of $15 \%$ humidity.

According to the water mass loss registered after each 24 hours, it was determined the wood drying rate with the following equation:

$$
\operatorname{Dr}=\frac{\text { Mwater }}{t . A}
$$

in which: Dr = drying rate for a determined humidity interval $\left(\mathrm{kg} / \mathrm{cm}^{2} . \mathrm{h}\right)$, Mwater $=$ water mass removed from wood $(\mathrm{kg}), \mathrm{t}=$ drying time $(\mathrm{h}), \mathrm{A}=$ evaporation area $\left(\mathrm{cm}^{2}\right)$.

The wood drying rate in each treatment was calculated using the area of a prism to the humidity intervals varying from saturated until $30 \%$, from saturated until $15 \%$, and from $30 \%$ until $15 \%$ humidity, according to the formula:

$T A=2(a \cdot b+a \cdot c+b \cdot c)$
in which: $\mathrm{TA}=$ total area $\left(\mathrm{cm}^{2}\right) ; \mathrm{a}, \mathrm{b}$ and $\mathrm{c}=$ prismatic sample faces' measures $(\mathrm{cm})$.

\section{Wood density and permeability}

After the drying process, the prismatic samples were lathed in order to obtain cylindrical pieces with 2.0 $\mathrm{cm}$ of diameter. Then, they were sectioned in $5.0 \mathrm{~cm}$ to obtain the sample to density and permeability test.

The volume of cylindrical samples was obtained through Mercury $(\mathrm{Hg})$ imertion in order to determine the aparent density $(15 \%)$ of all samples already in balance and, after the permeability test, the basic density through the gravimetric method was performed. Mercury temperature was measured after each eight weighing with a digital thermometer $\left( \pm 0,2^{\circ} \mathrm{C}\right)$.

To the permeability test the same dimentions described by other authors were adopted (BARAÚNA et al., 2014; TAGHIYARI et al., 2012; TAGHIYARI et al. 2015). To the final dimentipons, the samples had their longitudinal face waterproofed with maritime varnish with polyurethane base (two applications). Four flow meters

FLORESTA, Curitiba, PR, v. 49, n. 3, p. 579 - 586, jul/set 2019 
linked in series in the following scales and sequences were used to determine the wood permeability regarding atmospheric air: 0.04 to 0.5 LPM (Liters per Minute); 0.2 to 2.5 LPM; 0.4 to 5.0 LPM and 2.0 to 25.0 LPM. Then, in one of the flow meters series extremities it was connected a vacuum pump, and on the other extremity the samples were connected. The following equation was used for the determination of air wood permeability:

$$
K g=\frac{\text { Q. L.Pi }}{\text { A. } \Delta \text { P.Pa }}
$$

in which, $\mathrm{Kg}=$ gas permeability $\left(\mathrm{cm}^{3} / \mathrm{cm}\right.$.atm.s), $\mathrm{Q}=$ gas flow volume that travels the species $\left(\mathrm{cm}^{3} / \mathrm{s}\right), \mathrm{L}=$ length of sample $(\mathrm{cm}) ; \mathrm{Pi}=$ entrance pressure, the one from the environment $(\mathrm{atm}) ; \mathrm{A}=$ transversal section area $\left(\mathrm{cm}^{2}\right)$; $\Delta \mathrm{P}=$ pressure difference $(\mathrm{atm}) ; \mathrm{Pa}=$ average pressure in the sample $(\mathrm{atm})$

\section{Statistical analyses}

For the anatomical, chemical, density and drying rate variables, being accepted residues statistical requirements of normality (Shapiro-Wilk, at 5\% of significace) and homogeneity of variance (Bartlett, at 5\% of significace), methods of parametrical analyses (ANOVA) with completly randomized design were adopted, considering: three radial positions; two vaporization periods (12 and 24 hours); and two nanoparticles impregnation levels (with and without vacuum impregnation). Tukey test was used for comparison of the averages at $95 \%$ level of reliability, all the times that nullity hypothesis was rejected. The statistical analysis used for permeability was the non parametric test of Kruskal-Wallis (95\% probability) for the comparison of the average stages, due to the fact that the data did not follow a normal distribution (teste de Lillefors). After this test, the analysis by Dunn test was carried out in order to compare averages ( $95 \%$ probability).

\section{RESULTS}

\section{Anatomical and chemical analyses}

Diameter, area and vessels analyses did not present significant differences (at 95\% probability) between three radial regions, highlighting that statistically anatomical elements morphology did not modify in the radial direction of the wood and with vaporization use. At first, carbohydrates' content reduced with vaporization period increasing, as well as total extractives' content, which resulted in a total percentage increase of lignin in the samples (Table 2).

Tabela 2. Análises anatômicas e químicas para as três regiões radias da madeira: Transição Cerne/Alburno (TCA), Cerne Intermediário (CIT) e Cerne Interno (CIN), submetidas a diferentes períodos de vaporização.

Table 2. Anatomical and chemical analyzes for the three radiated positions of the wood: Heartwood/Sapwood Transition (HST), Intermediate Heartwood (ITH) and Internal Heartwood (INH), submitted to different periods of vaporization.

\begin{tabular}{clccccccccccc}
\hline $\begin{array}{c}\text { Radial } \\
\text { position }\end{array}$ & $\begin{array}{c}\text { Vapor } \\
(\mathrm{h})\end{array}$ & VD & VF & $\begin{array}{c}\text { Total } \\
\text { lignin } \\
(\%)\end{array}$ & Uro & Ace & Ara & Gal & Gli & Xil & Man $\begin{array}{c}\text { Total } \\
\text { Extractives }\end{array}$ \\
\hline \multirow{3}{*}{ HST } & Control & $128.2^{\text {ns }}$ & $9^{\text {ns }}$ & 36.63 & 3.01 & 1.5 & 0.1 & 1.2 & 43.0 & 8.8 & 1.1 & $6.91^{\mathrm{Ab}}$ \\
& $12 \mathrm{~h}$ & 129.5 & 11 & 36.74 & 3.00 & 1.3 & 0.1 & 1.0 & 42.9 & 8.4 & 0.8 & $7.11^{\mathrm{A}}$ \\
& $24 \mathrm{~h}$ & 131.7 & 10 & 38.51 & 2.88 & 1.1 & 0.1 & 1.0 & 41.6 & 7.8 & 0.6 & $5.36^{\mathrm{B}}$ \\
\hline \multirow{3}{*}{ ITH } & Control & $126.1^{\text {ns }}$ & $10^{\text {ns }}$ & 35.50 & 2.81 & 1.2 & 0.2 & 1.1 & 42.7 & 8.7 & 1.1 & $11.0^{\mathrm{Aa}}$ \\
& $12 \mathrm{~h}$ & 131.4 & 10 & 36.06 & 2.70 & 1.1 & 0.1 & 0.9 & 42.5 & 8.4 & 1.0 & $8.37^{\mathrm{B}}$ \\
& $24 \mathrm{~h}$ & 128.2 & 10 & 36.74 & 2.57 & 0.8 & 0.1 & 0.9 & 43.5 & 8.1 & 0.6 & $7.3^{\mathrm{B}}$ \\
\hline \multirow{2}{*}{ INH } & Control & $123.4^{\text {ns }}$ & $9^{\text {ns }}$ & 33.44 & 3.20 & 0.9 & 0.2 & 1.7 & 45.0 & 9.7 & 0.5 & $9.32^{\mathrm{Aa}}$ \\
& $12 \mathrm{~h}$ & 124.6 & 10 & 34.52 & 3.30 & 0.9 & 0.1 & 1.4 & 43.7 & 8.6 & 0.4 & $9.57^{\mathrm{A}}$ \\
& $24 \mathrm{~h}$ & 120.5 & 9 & 36.62 & 3.04 & 0.6 & 0.1 & 1.3 & 42.5 & 7.9 & 0.3 & $6.35^{\mathrm{B}}$ \\
\hline
\end{tabular}

$\mathrm{VD}=$ vessels diameter $(\mu \mathrm{m}) ; \mathrm{VF}=$ vessels frequency $\left(\mathrm{n}^{\circ} . \mathrm{mm}^{-2}\right)$; Uro = uronic acids; Ace = acetyl group; Ara = arabinan; Gal = galactan; Gli = glucan; Xil = xylan; Man = mannan; Extra T = total extractives; ${ }^{\text {ns }}$ : It express that there was not significative difference; $\left({ }^{\mathrm{AB}}\right)$ Averages followed by equal capital letters indicate that there was not difference between vaporization period in each radial position, at $5 \%$ of significance; $\left({ }^{\mathrm{a} . b}\right.$ ) Averages followed by equal lower-case letter indicate that there was not difference between positions to control sample, at $5 \%$ of significance.

The total extractives content average for wood was 9.07\%. A significant increase of contents was observed, when analyzing extractives content in pith towards the vascular cambium direction, because of the heartwood presence in the most interior wood parts. The vaporization caused a significant reduction in total extractives' content. In vaporized wood for $12 \mathrm{~h}$ only the intermediate heartwood (ITH) region presented reduction, while vaporization for $24 \mathrm{~h}$ resulted in an average decreasing of $29,31 \%$ in total extractives' content. 


\section{Air permeability and density}

Wood basic density in the three radial regions did not differ statistically, even when submitted to vaporization and nanoparticles impregnation. Density varied between 0.843 to $0.857 \mathrm{~g} / \mathrm{cm}^{3}$. The results obtained to air permeability (k) of E. pellitta wood showed a variation between the radial position. The heartwood regions (INH and ITH) present values significantly inferior to the portions that contain sapwood (Table 3). Wood permeability in sapwood region was about 15 times superior to internal heartwood (INH) region. This denotes that capillary contents affect significantly fluids' and gases' flow.

Tabela 3. Densidade básica e permeabilidade ao ar nas três regiões radiais.

Table 3. Basic density and air permeability in the three radial regions.

\begin{tabular}{lcccccc}
\hline \multirow{2}{*}{ Treatment } & \multicolumn{3}{c}{ Basic density $\left(\mathrm{g} / \mathrm{cm}^{3}\right)$} & \multicolumn{3}{c}{ Air permeability $(\mathrm{K})$} \\
\cline { 2 - 7 } \multicolumn{1}{c}{ Control } & HST & ITH & INH & HST & ITH & INH \\
\hline NV & $0.857(0.22)$ & $0.831(0.02)$ & $0.827(0.05)$ & $458.983^{*}$ & 50.128 & 30.989 \\
WV & $0.843(0.09)$ & $0.827(0.04)$ & $0.825(0.06)$ & $448.803^{*}$ & 30.958 & 36.848 \\
12h & $0.842(0.20)$ & $0.828(0.03)$ & $0.824(0.06)$ & $449.645^{*}$ & 71.727 & 27.462 \\
$24 \mathrm{~h}$ & $0.843(0.15)$ & $0.826(0.04)$ & $0.824(0.11)$ & $469.473^{*}$ & 31.372 & 22.748 \\
\hline
\end{tabular}

$\mathrm{NV}=$ nanoparticles with vacuum application; WV = nanoparticles without vacuum application; HST = Heartwood/Sapwood Transition Zone, ITH = Intermediate Heartwood; INH = Internal Heartwood. ( ): Variation coefficient, *: it expreess difference at 5\% of significance between wood radial positions.

However, even with reduction of extractive content and carbohydrates caused by vapor application, there was not significant increase in air flow in vaporized wood in relation to the non-vaporized one. The treatments with nanoparticles impregnations did not improve air longitudinal permeability.

The radial profile of E. pellita wood permeability presents a natural tendency, once the heartwood region present vascular cells with the lumen obstructed by thyllos, as well as by extractives (Figure 1).
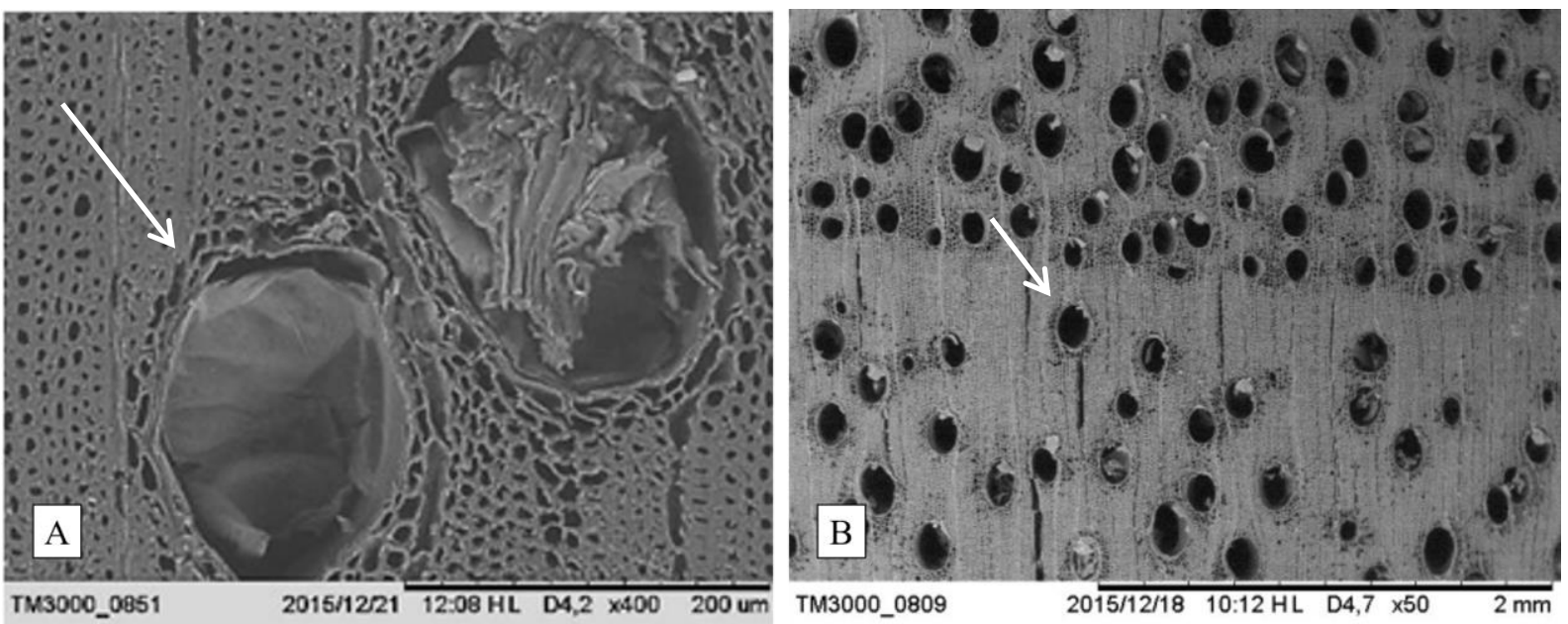

Figura 1. Obstrução dos vasos (indicada por setas) do cerne por tiloses (A) e vasos desobstruídos na região de transição entre o cerne e o alburno (TCA) (B).

Figure 1. Obstruction of the heartwood vessels (indicated by arrows) by tyloses (A) and unobstructed vessel in the transition region between heartwood and sapwood (HST) (B).

\section{Drying rate}

Drying rate in wood without treatment was $0.382 \mathrm{~kg} / \mathrm{cm}^{2} . \mathrm{h} .\left(10^{-4}\right)$, presenting a difference between humidity range saturated-30\% (free water) and 30-15\% (hygroscopic water). After the treatments' application, hygroscopic water and free exits presented higher influence of vaporization and nanoparticles impregnation, respectively (Table 4). Therefore, the highest drying rate in heartwood/sapwood transition zone radial position (HST), that is, in samples containing sapwood portions.

Tabela 4. Taxa de secagem das três regiões radiais em todos os tratamentos e nas fases de capilaridade e difusão $\left(\mathrm{kg} / \mathrm{cm}^{2} \cdot \mathrm{h} \cdot\left(10^{-4}\right)\right)$. 
Table 4. Drying rate of the three radial regions in all treatments and in the capillary and diffusion phases $\left(\mathrm{kg} / \mathrm{cm}^{2} \cdot \mathrm{h} \cdot\left(10^{-4}\right)\right)$.

\begin{tabular}{|c|c|c|c|c|c|c|c|}
\hline \multirow{2}{*}{\multicolumn{2}{|c|}{ Treatments }} & \multicolumn{2}{|c|}{$\begin{array}{c}\text { Humidity range } \\
\text { (Radial positions' average) }\end{array}$} & \multicolumn{3}{|c|}{$\begin{array}{l}\text { Radial position } \\
\text { (Saturated }-15 \%)\end{array}$} & \multirow{2}{*}{$\begin{array}{c}\text { Total } \\
(\text { Saturated }-15 \%)\end{array}$} \\
\hline & & Saturated $-30 \%$ & $30 \%-15 \%$ & HST & ITH & INH & \\
\hline \multirow{3}{*}{ 官 } & WV & $\begin{array}{l}0.806^{\mathrm{b}} \\
(0.29)\end{array}$ & $\begin{array}{l}0.307^{\mathrm{c}} \\
(0.06)\end{array}$ & $\begin{array}{c}0.417^{\mathrm{c}} \\
(0.10)\end{array}$ & $\begin{array}{c}0.351^{\mathrm{b}} \\
(0.05)\end{array}$ & $\begin{array}{c}0.378^{\mathrm{b}} \\
(0.06)\end{array}$ & $\begin{array}{r}0.382^{\mathrm{c}} \\
(0.08)\end{array}$ \\
\hline & $12 \mathrm{~h}$ & $\begin{array}{c}0.806^{b} \\
(0.38)\end{array}$ & $\begin{array}{c}0.369^{b} \\
(0.09)\end{array}$ & $\begin{array}{c}0.504^{b} \\
(0.17)\end{array}$ & $\begin{array}{c}0.435^{\mathrm{a}} \\
(0.11)\end{array}$ & $\begin{array}{c}0.425^{b} \\
(0.10)\end{array}$ & $\begin{array}{c}0.455^{\mathrm{b}} \\
(0.13)\end{array}$ \\
\hline & $24 \mathrm{~h}$ & $\begin{array}{c}0.974^{\mathrm{a}} \\
(0.37)\end{array}$ & $\begin{array}{c}0.411^{\mathrm{a}} \\
(0.09)\end{array}$ & $\begin{array}{c}0.615^{\mathrm{a}} \\
(0.11)\end{array}$ & $\begin{array}{c}0.438^{\mathrm{a}} \\
(0.07)\end{array}$ & $\begin{array}{c}0.498^{\mathrm{a}} \\
(0.11)\end{array}$ & $\begin{array}{l}0.515^{\mathrm{a}} \\
(0.12)\end{array}$ \\
\hline \multirow{3}{*}{$\begin{array}{l}\stackrel{̊}{\Xi} \\
\text { Z }\end{array}$} & WN & $\begin{array}{l}0.806^{\mathrm{b}} \\
(0.29)\end{array}$ & $\begin{array}{c}0.307^{\mathrm{b}} \\
(0.06)\end{array}$ & $\begin{array}{c}0.417^{\mathrm{b}} \\
(0.10)\end{array}$ & $\begin{array}{c}0.351^{\mathrm{ns}} \\
(0.05)\end{array}$ & $\begin{array}{l}0.378^{\mathrm{a}} \\
(0.06)\end{array}$ & $\begin{array}{c}0.382^{\mathrm{b}} \\
(0.08)\end{array}$ \\
\hline & NVac & $\begin{array}{c}0.674^{b} \\
(0.13)\end{array}$ & $\begin{array}{c}0.337^{\mathrm{b}} \\
(0.07)\end{array}$ & $\begin{array}{c}0.438^{b} \\
(0.11)\end{array}$ & $\begin{array}{l}0.377^{\mathrm{ns}} \\
(0.06)\end{array}$ & $\begin{array}{c}0.376^{b} \\
(0.05)\end{array}$ & $\begin{array}{c}0.397^{\mathrm{b}} \\
(0.08)\end{array}$ \\
\hline & WVac & $\begin{array}{c}1.152^{\mathrm{a}} \\
(0.11)\end{array}$ & $\begin{array}{c}0.403^{\mathrm{a}} \\
(0.11)\end{array}$ & $\begin{array}{c}0.657^{\mathrm{a}} \\
(0.13)\end{array}$ & $\begin{array}{l}0.439^{\mathrm{ns}} \\
(0.12)\end{array}$ & $\begin{array}{c}0.479^{\mathrm{a}} \\
(0.12)\end{array}$ & $\begin{array}{c}0.525^{\mathrm{a}} \\
(0.15)\end{array}$ \\
\hline
\end{tabular}

Interaction

ns

ns

ns

ns

ns

ns

$\mathrm{WV}=$ without vapor; $\mathrm{WN}=$ without nanoparticles; Nvac = without vacuum application; Wvac = with vacuum aplication; HST = Heartwood/Sapwood Transition Zone; ITH = Intermediate Heartwood; INH = Internal Heartwood; Saturated $-30 \%=$ capilarity fase; $30 \%$ $15 \%=$ diffusion fase; ()$=$ variation coefficient; $n s=$ not significant at $5 \%$ of significance; $\left({ }^{\text {a.b }}\right)$ Averages followed by equal letters indicate that there was no difference between treatments at $5 \%$ of significance.

Wood vaporization for $24 \mathrm{~h}$ was more efficient than $12 \mathrm{~h}$ period in total drying rate (saturated at $15 \%$ ), also in capilarity and diffusion. However, silver nanoparticles incorporation in wood with previous vacuum application resulted in higher increase in drying rate because of the benefits before and after saturation point of fibers. It was possible to observe nanoparticles' deposition location, after previous vacuum application, in the surface of vessels walls as well as inside fibers' walls ultrastructure (Figure 2).
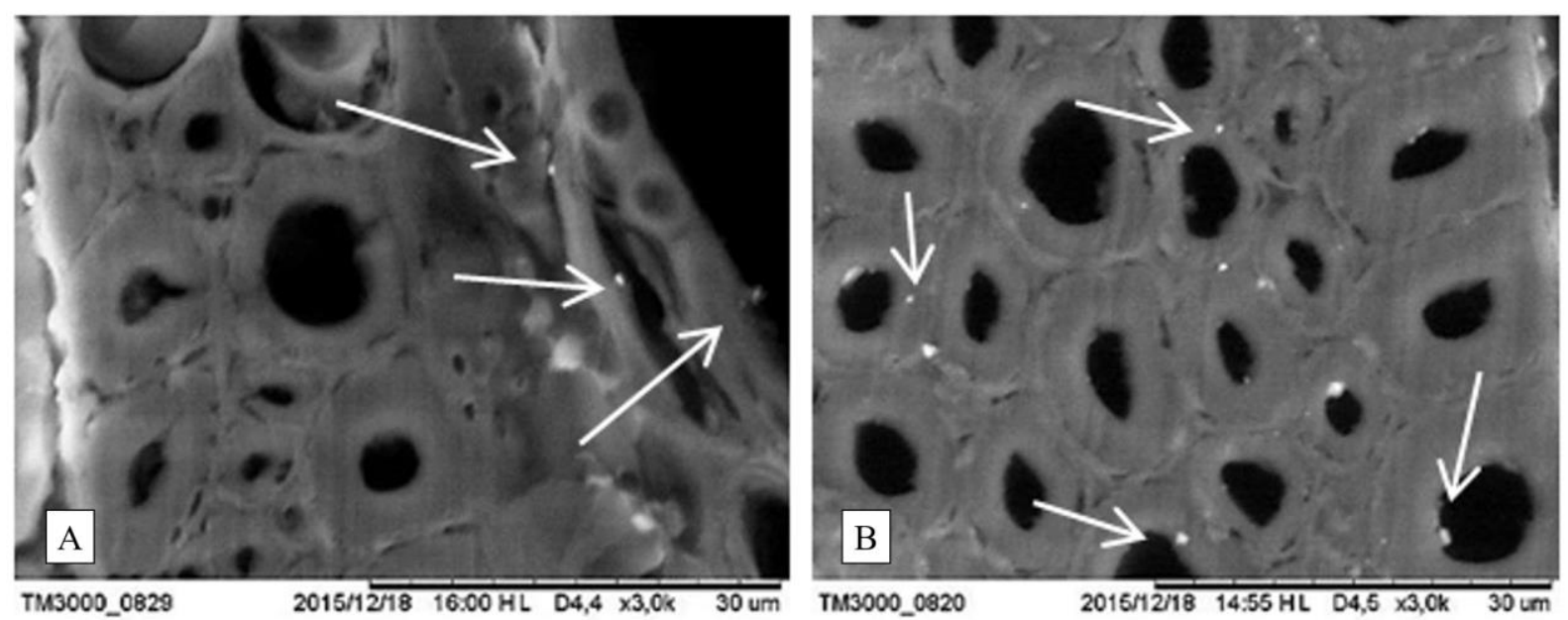

Figura 2.Deposição de nanopartículas de Ag (indicadas por setas) observada em microscópio eletrônico de varredura. (A) Impregnadas na parede do vaso. (B) Impregnadas na parede das fibras.

Figure 2. Deposition of Ag nanoparticles (indicated by arrows) observed in a scanning electron microscope. (A) Impregnated in the vessel wall. (B) Impregnated in the wall of the fibers.

\section{DISCUTION}

In all vapor treatments the sugar content reduced. This effect can be explained by molecular mass loss that occurs in hemicellulose polymer when vapor is directed towards the wood (PERSSON; JÖNSSON, 2017). 
One of the reactions responsible for this molecular mass loss is the acetylation that occurs in acetyl group present in the ramifications of hemicelluloses' chains, transforming them in acetyl group monomer and defragmenting hemicelluloses' chains (JOHNSON et al., 2017) due to the easy access promoted by amorphous regions of the cellulose chain (CALONEGO et al., 2014). Therefore, vapor application modifies wood chemical composition. The presence of volatile extractives in E. pellita wood contributed to total extractives content reduction, due to a possible leaching and/or degradation of these components during the process of vaporization (DASHTI et al., 2012; TAGHYARI et al., 2014). Carbohydrates and extractives content reduction also interefe in hygroscopic properties of wood cell wall (BAL; BEKTAS, 2012; CALONEGO et al., 2014). Vascular cambium direction permeability increase can be explained, mainly, by the distinct characteristics between heartwood and sapwood, that is, reduction of extractives content and absence of thyllos in sapwood. Thus, there is an inverse relation between extractives content and wood drying rate due to the obstruction of vessels by starch and resins (DASHTI et al., 2012; PAES et al., 2013).

E. pellita wood drying rate presented an increase after vapor treatment for $24 \mathrm{~h}$. Similar results were obtained by Rezende et al. (2015) in planks of E. grandis submetted to vaporization $\left(90^{\circ} \mathrm{C}\right.$ and $100 \%$ of relative humisity for $3 \mathrm{~h}$ ), which promoted significant increase in drying rate for the studied species. Drying rate increase can be directly related to the permeability increase and to the diffusivity parameters of wood (DASHTI et al., 2012). Vapor pre-treatment, depending on the period, can cause modifications in cell wall ultrastructure (JHONSON et al., 2017) and this type of modification can interfere in hygroscopic water exit rate (CALONEGO et al., 2014). Hence, temperature increase in wood treatments has direct influence in adsorption capacity of cell wall; due to the inactivation or neutralization of adsorption sites (hydroxyl groups) found in the wall, resulting from cellulose and hemicellulose chains rearrangement as well as migration and/or extractives loss (BAL; BEKTAS, 2012). These chemical rearrangements promoted by vaporization modify positively, reducing water exit access quantity, denotating significant effect in water movement by diffusion.

Moreover, it was possible to note nanoparticle presence on the cell wall (Figure 3), since they can adhere on the wall surface or even penetrate it (MONTAZER; ALIMOHAMMADI, 2012). The significant air permeability increase obtained by nanoparticles depends on the impregnation method. The process of empty-cell is an effective method due to the forced clearance that the pressure causes in the vessels (TAGHIYARI et al., 2014; TAGHIYARI et al., 2015). The drying rate increase after silver nanoparticle immersion also was observed by Lotfizadeh et al. (2012) in Populus nigra wood. Besides, Taghiyari and Layeghi (2012) verified that silver nanoparticles impregnation and thermical treatments reduced water adsorption capacity in $P$. nigra, $P$. deltoides and Fagus orientalis wood. This result, according to the authors, occurred due to the silver low hygroscopicity and carbohydrates content reduction by thermical treatment (TAGHIYARI et al., 2015; JHONSON et al., 2017).

\section{CONCLUSIONS}

- Vapor wood treatment for 24 hours period reduces total extractives content of wood contributing to the increase of drying rate;

- In wood that present thyllos, heartwood permeability does not modify in vaporization processes;

- Physical properties (basic density and permeability) of E. pellita wood are not affected significantly by vaporization and silver nanoparticles impregnation;

- 24 hours vaporization and silver nanoparticles incorporation with previous vacuum application contribute to the significant drying rate increase in E. pellita wood, before as well as after fibers' saturation point.

\section{ACKNOWLEDGEMENTS}

To KHEMIA nanopartículas LTDA company for providing the necessary material to the research; and to Coordination for the Improvement of Higher Level Personnel (CAPES) for the research financing grant.

\section{REFERENCES}

ABREU, S.; CARVAlHO, A. M.; MONTEIRO, M. B.; PEREIRA, R. P. W.; ROCHA E SILVA, H.; SOUZA, K. C. A.; AMPARO, K. F.; CHALITA, D. B. Métodos de análise em química da madeira. Floresta e Ambiente, Seropédica, $\mathrm{n}^{\circ}: 1$, p. 1 - 20, 2006.

ALEXIOU, P. M.; WILKINS, A. P.; HARTLEY, J. Effects of pre-steaming on drying rate wood anatomy and shrinkage of regrowth Eucalyptus pilularis Sm. Wood Science and Technology, Berlin, v. 24, n. 1, p. 103 - 110, 1990.

BAL, B. C.; BEKTAS, I. The effects of heat treatment on physical properties of juvenile wood and mature wood of Eucalyptus grandis. Bioresources, Raeligh, v. 7, n. 4, p. 5117 - 5127, 2012.

FLORESTA, Curitiba, PR, v. 49, n. 3, p. 579 - 586, jul/set 2019.

Pace, J. H. C. et.al.

ISSN eletrônico 1982-4688 
BARAÚNA, E. E. P.; LIMA, J. T.; VIEIRA, R. S.; SILVA, J. R. M.; MONTEIRO, T.C. Effect of anatomical and chemical structure in the permeability of "Amapá" wood. Cerne, Lavras, v. 20, n. 4, p. 529- 534, 2014.

CAlONEGO F. W.; SEVERO, E. T. D.; LATORRACA, J. V. F. Effect of Thermal Modification on the Physical Properties of Juvenile and Mature Woods of Eucalyptus grandis. Floresta e Ambiente, Seropédica, v. 21, n. 1, p. 108 $-113,2014$.

DASHTI, H.; SALEHPUR, S.; TAGHIYARI, H. M.; AKBARI FAR, F.; HESHMATI, S. The Effect of Nanoclay on the Mass Transfer Properties of Plywood Digest. Bioresources, Raeligh, v. 7, n. 3, p. 853 - 860, 2012.

ELEOTÉRIO, J. R.; HORNBURG, K. F.; REICHERT, D.; BAGATTOLI, T. R.; MENEGHELLI, I. Efeito da espécie e da condição de secagem na formação de defeitos na madeira serrada de eucalipto. Scientia Forestalis, Piracicaba, v. 42, n. 101, p. $41-47,2014$.

GAO, L.; LU, Y.; LI, J.; SUN, Q. Superhydrophobic conductive wood with oil repellency obtained by coating with silver nanoparticles modified by fluoroalkyl silane. Holzforschung, Berlin, v. 70, n. 1, p. 1 - 6, 2015.

INTERNATIONAL ASSOCIATION OF WOOD ANATOMY COMITTEE. IAWA list of microscopic features for hardwood identification. IAWA Bulletin, v. 10, n. 3, p. 218 - 359, 1989.

JOHNSON, A. M.; KIM, H.; RALPH, J.; MANSFIELD, S. D. Natural acetylation impacts carbohydrate recovery during deconstruction of Populus trichocarpa wood. Biotechnology for Biofuels, Lund, v. 10, p. 48, 2017.

LOTFIZADEH, H., SHAHVERDI, M.; DASHTI, H.; TAGHIYARI, H. R. Potential usage of nanotechnology in wood drying: Treating poplar boards with nanometals affects the drying behavior. Digest Journal of Nanomaterials and Biostructures, Bucharest, v. 7, n. 4, p. 1627-1636, 2012.

LUÍS, R. C. G.; KLITZKE, R. J.; ROCHA, M. P. Efeitos da vaporização nas propriedades mecânicas de Eucalyptus saligna. Revista Científica Eletrônica de Engenharia Florestal, Garça, v. 30, n. 1, p. 15 - 23, 2017.

MONTAZER, M.; ALIMOHAMMADI, F. Sabilized nanosilver loaded nylon knitted ussing BTCA without yellowing. Process in Organic Coating, v. 74, n. 1, p. 270 - 276, 2012.

PAES, J. B.; NETO, P. N. M.; LIMA, C. R.; FREITAS, M. F. Efeitos de extrativos e cinzas na resistência natural de quatro madeiras a cupins xilófagos. Cerne, Lavras, v. 19, n. 3, p. 399 - 405, 2013.

PERSSON, T.; JÖNSSON, A. Characterization of hemicelluloses in process streams in thermomechanical and chemithermomechanical pulp mills. Journal of Wood Chemistry and Technology, Londres, v. 37, n. 1, p. 1 - 7, 2017.

REZENDE, R. N.; LIMA, J. T.; RAMOS E PAULA, L. E.; SILVA, J. R. M. Efeito da vaporização na secagem de tábuas de Eucalyptus grandis. Cerne, Lavras, v. 21, n. 1, p. 37 - 43, 2015.

SCOTT, E. W.; ABBOTT, J. C. Properties of paper - an introduction. Atlanta: TAPPI Press, 2 ed. 1995, 192 p.

SOLAR, R.; KACIK, F.; MELCER, I. Simple semimicro method for the Determination of O-Acetyl Groups in Wood and Related Materials. Nordic Pulp and Paper Research Journal, Halmsted, v. 4, p. 139-141, 1987.

TAGHIYARI, H. R.; KALANTARI, A.; GHORBANI, R.; BAVANEGHI, F.; AKHTARI, M. Effects of fungal exposure on air and liquid permeability of nanosilver- and nanozincoxide-impregnated Paulownia wood. International Biodeterioration and Biodegradation, Melboune, v. 105, n. 3, p. 51 - 57, 2015.

TAGHIYARI, H. R.; HABIBZADE, S.; MIRI TARI, S. M. Effects of Wood Drying Schedules on Fluid Flow in Paulownia Wood. Drying Technology, Quebec, v. 32, n. 1, p. 89-95, 2014.

TAGHIYARI, H. R.; LAYEGHI, M.; LIYAFOOEE, F. A. Effects of dry ice on gas permeability of nano-silverimpregnated Populus nigra and Fagus orientalis. IET Nanobiotechnology, Herts, v. 6, n. 2, p. 40, 2012.

TARMIAN, A.; REMOND, R.; DASHTI, H.; PERRÉ, P. Moisture diffusion coefficient of reaction woods: Compression wood of Picea abies L. and tension wood of Fagus sylvatica L. Wood Science and Technology, Berlin, v. 46, n. 1-3, p. $405-417,2012$

Technical Association of the Pulp and Paper Industry. TAPPI standard methods. Atlanta, 2000.

WALLIS, A. F. A.; WEARNE, R. H.; WRIGHT, P. J. Chemical analysis of polysaccharidesin plantation eucalypt woods and pulps. Appita Journal, Victória, v. 49, n. 4, p. 258 - 262, 1996. 